\title{
Kitap Değerlendirmesi: Şen, Abdurrahim. İslam Hukuk Düşüncesinde ìktidar ve Meşruiyet. (isstanbul: Klasik Yayınları, 2020), 213 Sayfa. ISBN: 978-975-248-447-4
}

\section{Mustafa Ince* ${ }^{*}$}

21. yüzyılda Orta Doğu'da yer alan Müslüman devletlerin devlet içi veya devletlerarası çatışmalarının artması sonucunda İslam'da iktidar ve iktidarın meşruiyeti zihinlere takılan önemli sorulardan biri olmuştur. Mevzubahis soru, insanları ilgili literatüre yöneltmişse de hakikatte bu alanda oldukça az çalışma bulunmaktadır. Bu noktada, İslam Hukuk Düşünesinde İktidar ve Meşruiyet, İslam'ın ilk dönemlerinden Osmanlıya kadar iktidar ve meşruiyet ilişkilerini ele alan kapsamlı bir eser olarak karşımıza çıkmaktadır. Eser Asya, Afrika, Arabistan yarımadası ve Anadolu' da kurulmuş olan İslam devletlerinin iktidar, güç ve meşruiyet ilişkilerini geniş çaplı, toparlayıcı ve açıklayıcı bir tarzda ele alması bakımından faydalı ve dikkate şayan bir eserdir. Lakin böyle geniş bir tarihsel çerçeve ve coğrafyayı ele almak bazı zaafları da beraberinde getirmektedir.

Kitabın yazarı olan Abdurrahim Şen'in akademik kariyerinde İslam siyaset düşüncesi üzerine araştırmaları önemli bir yekûn tutmaktadır. Değerlendirmemize konu olan bu eser, yazarın "İslam Hukuk Düşüncesinde İktidar-Güç İlişkisi (11. yüzyıldan 19. yüzyıla kadar)" isimli doktora tezinden kitaba çevrilmiştir. Yazarın bu tezi, yüksek lisansta yazdığ 1 "Hulefâ-i Râşidîn'in Halife Seçilme Şekilleri” isimli tezinin bir noktada devamı niteliğindedir. Zira yazar, yüksek lisans tezinde İslam'ın ilk döneminde iktidarın belirlenme biçimleri üzerinde çalışmıştır. Bu tez de ilk dönemde iktidarın meşruiyeti, iktidar yetkisini kullanan kişilerde aranan şartlar ve iktidarın kurulma şekli meselelerine ışık tutmaktadır. Çünkü yazar, kitapta esas olarak 11. ve 19. yüzyıllar arasını incelemekte, önceki süreçlere ise yalnızca değinerek atıflar yapmaktadır. Dolayısıyla yazarın daha önce yaptığı çalışmalar da söz konusu kitapta ele aldığı çalışmalar ile irtibatıdır. Ayrıca yazar incelediği dönemin birincil kaynakları olan 
Cüveynî (v. 478/1085), Gazzâlî (v. 505/1111), İbn Teymiyye (v. 728/1328) ve İbn Haldûn'un (v. 808/1406) eserlerine başvurarak bu kitabı oluşturmuştur. Böylece kitabın ortaya koyduğu tespitler güçlendirilmiştir.

Giriş kısmı hariç tutulduğunda kitap üç bölümden oluşmaktadır.Kitabın birinci bölümünde iktidar ve meşruiyet kavramlarıyla birlikte iktidarın meşruiyet kaynağ1, meşru bir iktidarın kuruluş şekli ve şartları İslam hukuku çerçevesinde incelenmiştir. Bu bölüm içerisinde iktidar velâyet-i âmme kavramı üzerinden ele alınmış ve iktidarın meşruiyeti de akit teorisi bağlamında işlenmiştir. Bununla birlikte meşruiyetin şartları başlığı altında da meşruiyetin kaynağı olan biat akdi, akdin tarafları ve akdin konusu üzerinde durulmuştur. İkinci bölüm, yazarın da ifade ettiği üzere kitabın ana konusu olan iktidar-güç ilişkisi üzerinedir (s.7). Bu bölümde toplum içi sosyal gücü ifade eden şevket kavramı ile iç veya dış düşmanlara karşı caydırıcı fiziksel gücü ifade eden menea kavramı etrafında iktidarın sosyal ve fiziksel gücü, zamanla bu güce yapılan vurgunun değişmesi ve meşruiyet-güç ilişkisi üzerinde durulmuştur. Son bölüm olan üçüncü bölüm ise istila konusuna yani iktidarın güç kullanılarak elde edilmesine dairdir. Bu bölümde iktidarın güç ile ele geçirilmesi bir meşruiyet krizi olarak ele alınmıştır.

Yukarıda da izah edildiği üzere kitabın ana bölümleri meşruiyet, iktidar (velâyet- $i$ âmme), biat akdi, şevket, menea ve istila kavramları üzerinden teorize edilmektedir. Buna göre İslam' da iktidarın kaynağı akit ehli ve imam arasında yapılan biat akdine dayanmakta ve bu akit var ise iktidar meşru kabul edilmektedir. İlk zamanlarda bu akdin taraflarından biri olan imamda Müslümanlık, akıl, Kureyşîlik vb. şartların aranması öne çıkarken özellikle on birinci yüzyıldan itibaren ortaya çıkan istikrarsızlık sebebiyle şevket ve menea kavramlarına yani sosyal ve fiziksel güce vurgu öne çıkmaktadır. Lakin burada vurgulanan güç; Gibb, Rosental, Lewis, Crone ve Black gibi Batılı düşünürlerin iddia ettiği üzere İslam siyaset düşüncesinin kaba güce dayanan meşrulaştırma faaliyeti şeklinde bir güç değildir (s.89). Zira İslam'da "hukuki açıdan bir iktidara meşruiyet kazandıran şey ise iktidarın kaba gücü değil, seçici kurulun biat ederek toplum-içi güç dengelerini o kimsenin iktidarına rıza ve onay verecek biçimde sirküle etmesidir" (s.90). Buradan yola çıkarak istila yoluyla iktidarı ele geçirmeye çalışan kişinin iktidarı ancak bazı şartlar altında geçerli olmaktadır. "Bu şartlar biat alma, zaruret halinde ve siyasi boşluğun oluşturduğu bir konjonktürde gerçekleşme, gerçekleştiğinde istikrar ve güvenliği sağlamış olma ve meşru bir iktidara karşı olmama şeklinde tasnif edilebilir" (s.164).

Yazar kitapta önemli tespitlerde bulunmaktadır. Bu tespitlerden iki tanesi İslam' da iktidar olgusunun anlaşılması bakımından diğer tespitlere nazaran daha fazla öne çıkmakta ve kitabın genelinde hâkimiyetini sürdürmektedir. Söz konusu tespitlerden 
ilki İslam'da iktidar meşruiyetinin güce değil akde dayalı bir meşruiyet olduğudur. İkinci tespit ise Abbasiler Devleti'nin sonlarına doğru Moğol istilası ve Haçlı seferleri gibi büyük askeri tehlikeler karşısında, İslam âleminin beka ve istikrar problemi yaşaması sonucunda, "bu dönemlerin fakih ve teorisyenlerinin iktidar yetkisini kullanan imamda veya ona uygulama yetkisini veren seçici kurulda aranan şartlar bağlamında güç ve kudret niteliğine vurgu" yapmalarıdır (s.7).

Abbasiler Devleti'nin sonlarına doğru halifeliğin güç kaybedip sembolik bir hale geldiği müellif tarafindan tespit edilmiştir. Bu durumda halifelik daha çok şevket ve menea sahibi Selçuklu ve Memlük Devletleri'nin koruması altında faaliyet sürdürmüştür. Yani imametin/hilafetin zorunluluk şartı olan İslam ahkâmının tenfîzi bu devletlerin sultanları tarafından yürütülüyor iken halifelik sembolik bir makam haline dönüşmekte ve kısıtlı yetkilere sahip olmaktadır. Bir başka ifade ile, halife ve sultan bazı konulardan birbirlerinin lehine el çekmektedirler. Bu durumda halifeliğin rolü nedir? Zira böyle bir durumda halifeliğin halk arasında sultanın meşruiyet kaynağ1 olarak kullanılması mümkündür. Yani normalde halifelik, meşruiyetini halka borçlu olan bir kurum iken bir süre sonra halk adına meşruiyet veren bir kaynak haline mi gelmiştir? Kitabın bu konuya dair incelemesi daha da genişletilebilir. Zira böyle bir durumda iktidar algısında bir değişiklik olmakla birlikte halife, iktidarın kendisi olma görevini sultana terk edip kısıtlı yetkilere sahip bir şekilde, iktidara meşruiyet veren seçici kurula dâhil olmaktadır.

Kitabın ikinci bölümünde ele alınan konulardan birisi olan Osmanlı hilafetinin meşruiyeti başlığı altında Osmanlı Devleti’nin şevket ve menea gücünün yüksek olması hasebiyle şer'i ahkâmın tatbikini sağlama imkânına sahip oluşu, böylece halifeliği meşru bir şekilde elde edişinden bahsedilmiştir. Lakin Osmanlıların, hilafeti kendi bünyelerine alırken Memlük Devleti'nin, Abbasilerin sonlarında Moğol saldırılarını def edecek şekilde menea ve şevkete sahip olmalarına rağmen hilafeti kendilerine almayıp Abbasoğullarının ellerinde bırakması meselesi bizce izaha muhtaçtır. Bununla birlikte Osmanlı Devleti'nin hilafeti kendi bünyesine alması noktasında Moğol siyasi kültürünün ve iktidar anlayışının Osmanlı siyasi kültürüne ve iktidar anlayışına etkisi de izahı gerektirmektedir.

Yazarın incelediği tarih ve coğrafya aralığının geniş olması bu ve bunun gibi birkaç noktanın göz ardı edilmesine sebebiyet vermiş̧tir. Örneğin Emevilerin mevâlî politikası karşısında Kureyşîlik vurgusunun devam edip etmediği ve bu noktada Kureyşîlik vurgusuna itirazların varlığı da izaha muhtaçtır. Bununla bitlikte kitabın tarihsel bir arka plan içermesi hasebiyle iktidarın meşruiyeti teorisinin pratikte olan yansımalarına da pek fazla yer verilmemiştir. Zira Emevîler, Abbasiler, Selçuklular, Memlükler ve Osmanlı Devleti iktidar ve güç ilişkisi bağlamında 
detaylı bir şekilde incelenmiştir. İktidar ve meşruiyet ilişkisi bağlamında ise Emevîler Devleti ve Osmanlı Devleti üzerine önemle durulurken diğer devletler üzerinde daha az durulmuştur.

Sonuç olarak kitap boyunca kendini gösteren en temel fikir İslam'da imametin yani halifeliğin aslında kaba güç hâkimiyetine dayalı olmadığı, aksine toplum üzerinde etki sahibi seçici bir kurul ile imam arasında yapılan akde dayalı olduğudur. Bu şekilde kurulan iktidar meşru olmakta ve bunun sonucu olarak da halifeye insanlara hükmetme yetkisi vermektedir. Hükmetme yetkisi de sosyal bir gücü gerektirmekte ve söz konusu sosyal güç şevket kavramıla ifade edilmektedir. Hüküm faaliyetinin devamlılığının dışarıdan veya içeriden kaynaklı herhangi bir güç tarafindan engellenmemesi için fiziksel bir güce ihtiyaç duyulmakta ve bu da menea kavramıla ifade edilmektedir. Lakin burada iktidar, olgusal güce dayanmamaktadır. Tarih içerisinde güce yapılan vurgu da tarihsel olaylar bağlamında değişime uğramaktadır. Kitabın aktardığı bu ana tez birbiriyle irtibatlandırılmış ve cüz'î örneklerle güçlendirilmiştir. Bu sebeple genel teori tutarlı bir şekilde kurulmuştur. Fakat incelenen devlet sayısının oldukça fazla olması tarihsel ve coğrafi süreci oldukça genişletmiş, bazı noktalar mecburen göz ardı edilmiştir. Buna rağmen kitap, gerek başlığı ve gerekse girişte belirtilen amaçları ile uyumlu bir şekilde bina edilmiştir. Böylece yazar, ifade etmeyi amaçladığı konuyu tutarlı ve teorik bir biçimde ortaya koymuştur. 